\title{
Feasibility Study of Tetracycline Removal by Ozonation Equipped with an Ultrafine-Bubble Compressor
}

\author{
Chikang Wang ${ }^{1, *} \mathbb{D}$, Chien-Yu Lin ${ }^{1,2}$ and Guan-Yun Liao ${ }^{1}$ \\ 1 Department of Environmental Engineering and Health, Yuanpei University of Medical Technology, \\ Hsinchu 300, Taiwan; lin7010@mail2000.com.tw (C.-Y.L.); otuz524@gmail.com (G.-Y.L.) \\ 2 Department of Internal Medicine, En Chu Kong Hospital, New Taipei City 237, Taiwan \\ * Correspondence: ckwang@mail.ypu.edu.tw; Tel.: +886-3-6102313
}

Citation: Wang, C.; Lin, C.-Y.; Liao, G.-Y. Feasibility Study of Tetracycline Removal by Ozonation Equipped with an Ultrafine-Bubble Compressor. Water 2021, 13, 1058. https:// doi.org/10.3390/w13081058

Academic Editor: Zacharias Frontistis

Received: 10 March 2021

Accepted: 9 April 2021

Published: 12 April 2021

Publisher's Note: MDPI stays neutral with regard to jurisdictional claims in published maps and institutional affiliations.

Copyright: (c) 2021 by the authors. Licensee MDPI, Basel, Switzerland. This article is an open access article distributed under the terms and conditions of the Creative Commons Attribution (CC BY) license (https:// creativecommons.org/licenses/by/ $4.0 /)$.

\begin{abstract}
In this study, a combination of an ozone gas producer and an ultrafine-bubble compressor was used to degrade tetracycline, which is a well-known antibiotic and medicine commonly used in human and animal care, and effects of varying the reaction parameters were studied. Experiments indicate that each gram of introducing ozone can degrade $2.72 \mathrm{~g}$ of tetracycline at $\mathrm{pH} 3$ and $1.48 \mathrm{~g}$ at $\mathrm{pH} 11$. However, basic conditions contribute to increased mineralization of tetracycline because of the $\cdot \mathrm{OH}$ radical oxidation mechanism. Higher reaction temperatures and higher ozone dosages enhance the reactivity between the ozone molecules, $\cdot \mathrm{OH}$ radicals, and tetracycline, resulting in a decline in the toxicity of the tetracycline solution as measured by cell viability. The mineralization of organic compounds is the key to decreasing the toxicity of the solution. Ultrafine-bubble ozonation can provide homogeneity of gas bubbles in solution hence it not only reduces the requirement of ozone and thus the operational cost of the reaction, but also extends the efficacy of the method to the treatment of solutions with high tetracycline concentrations.
\end{abstract}

Keywords: cell viability; mineralization; tetracycline; toxicity; ultrafine-bubble ozonation

\section{Introduction}

More than 4000 pharmaceutical medicines are currently in use around the world, and the annual total global antibiotic consumption is estimated to be $100,000-200,000$ tons. Because of excessive consumption and the disposal of unused or expired antibiotics, these compounds are released into the environment in large quantities. In Europe, about 15,000 tons of antibiotics are discharged into the environment every year [1,2]. In Taiwan, more than 1600 tons of antibiotics are used each year, of which $70 \%$ are used in animal husbandry feed additives. In China, annual antibiotic consumption per person was about $138 \mathrm{~g}$, which is 10 times that of the United States [3]. The abuse of antibiotics all over the world has significantly increased the resistance of bacteria to current antibiotics and led to more than 25,000 deaths due to drug-resistant bacteria in Europe each year [4,5].

Tetracycline was discovered in 1940 and is one of a family of antibiotics that inhibits protein synthesis by preventing aminoacyl-tRNA from connecting to the ribosomal receptor (A) seat [6]; its molecular structure is shown as Figure 1. Its broad effectiveness and strong therapeutic performance have led to the widespread use of tetracycline as a broad-spectrum antibiotic. Tetracycline has been widely used in animal husbandry, agriculture, aquaculture, fisheries, veterinary medicine, and human treatment globally [7]. It is often used in the treatment or control of human diseases and as an additive to animal feed to prevent diseases and promote growth [8]. Because tetracycline is not completely metabolized by humans or animals, approximately $60 \%$ of the tetracycline ingested is excreted in urine and discharged to the environment [9]. Even though the concentrations of tetracycline discharged are usually low, it can accumulate in the environment and result in severe contamination over time because of its high consumption by humans and animals [10]. 


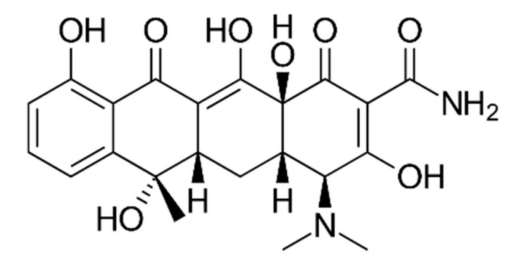

Figure 1. Molecular structure of tetracycline.

The formation of hydroxyl radicals $(\cdot \mathrm{OH})$ in solution is the key to converting organic compounds or pollutants into harmless products, especially $\mathrm{CO}_{2}$ and $\mathrm{H}_{2} \mathrm{O}$, because of the high reactivity and short lifetimes of $\cdot \mathrm{OH}$ radicals [11]. Once $\cdot \mathrm{OH}$ radicals are generated, they attack organic pollutants in three ways: electron transfer (redox reaction), Equation (1), hydrogen atom extraction abstraction (dehydrogenation), Equation (2), and electrophilic $\pi$ addition (hydration), Equation (3). In these equations, $\mathrm{RX}$ and $\mathrm{PhX}$ represent aliphatic and aromatic halides, respectively. These reaction mechanisms not only open the phenyl rings in organic compounds but also lead to reactions with oxygen to produce hydroperoxyl radicals. This results in the formation of intermediates or by-products such as $\mathrm{HO}_{2}$. and $\mathrm{H}_{2} \mathrm{O}_{2}$ that undergo further oxidation reactions until the organic compounds are fully mineralized [12]. Therefore, ultra-violet light, Fenton reactions, ultrasound, and ozonation have been used to destroy, degrade, or oxidize organic compounds, either by themselves or with the addition of $\mathrm{H}_{2} \mathrm{O}_{2}, \mathrm{TiO}_{2}$, and many types of iron [13-16] or non-iron based heterogeneous catalysts such as zeolites [17].

$$
\begin{gathered}
\cdot \mathrm{OH}+\mathrm{RX} \rightarrow \mathrm{RX}^{+} \cdot+\cdot \mathrm{OH}^{-} \\
\cdot \mathrm{OH}+\mathrm{RH} \rightarrow \mathrm{R} \cdot+\mathrm{H}_{2} \mathrm{O} \\
\cdot \mathrm{OH}+\mathrm{PhX} \rightarrow \mathrm{PhX}(\cdot \mathrm{OH}) \cdot
\end{gathered}
$$

Ozone is a triatomic oxygen molecule composed of an oxygen atom and a diatomic oxygen molecule. It is an unstable gas that rapidly decomposes into oxygen with a halflife of about $40 \mathrm{~min}$ at $20^{\circ} \mathrm{C}[18,19]$. This unstable $\mathrm{O}_{3}$ has a strong oxidizing ability to destroy pollutants. Ozone can easily degrade aromatic organic pollutants by destroying the aromatic rings to form intermediate products such as short-chain carboxylic acids, aldehydes, and ketones. However, direct ozone oxidation may not be sufficient to achieve the required degradation efficiency. Indirect oxidation by $\cdot \mathrm{OH}$ radicals augments the degradation efficiency because the $\cdot \mathrm{OH}$ radicals resulting from the reaction between ozone and water have a high oxidation potential [20].

An ultrafine-bubble compressor equipped with an ozone gas production unit was used for the degradation of tetracycline because ultrafine gas bubbles have a large specific surface area, high stability in solution, long life, self-pressurization, and long residence time [21,22]. If the diameter of the ozone bubbles is smaller than $50 \mu \mathrm{m}$, the mass transfer between the gas and solution phases is better than with a millimeter scale bubble, due to the higher specific interfacial area, slower rising velocity, and the higher inner pressure of the ozone gas bubbles, resulting in improvements to the solubility and treatment efficiency of target compounds in water [23]. The objective of this study was to investigate the feasibility of an ultrafine-bubble ozonation in the degradation, mineralization and detoxification of tetracycline at different reaction conditions. Degradation kinetics, operational costs, and degradation capacity of each gram of ozone on tetracycline were also investigated.

\section{Materials and Methods}

\subsection{Materials}

Commercial analytical-grade tetracycline (Merck, Germany, purity of $98 \%$ ) was used as the target species for ozonation. Other chemical reagents including sulfuric acid $\left(\mathrm{H}_{2} \mathrm{SO}_{4}\right)$, phosphoric acid $\left(\mathrm{H}_{3} \mathrm{PO}_{4}\right)$, sodium hydroxide $(\mathrm{Na} \cdot \mathrm{OH})$, potassium hydrogen phthalate 
$\left(\mathrm{C}_{8} \mathrm{H}_{5} \mathrm{KO}_{4}\right)$, and tert-butanol $\left(\left(\mathrm{CH}_{3}\right)_{3} \mathrm{C} \cdot \mathrm{OH}\right)$ were of the purest commercially available grade (from Merck or FERAK, Germany) and were used without further purification.

\subsection{Experimental Apparatus}

A schematic diagram of the experimental apparatus designed for tetracycline degradation has been shown in our previous study [24]. The reactions were performed in a Pyrex-glass cylindrical reactor (1 L working volume) with a cooling jacket and a circulating temperature controller to keep the reaction temperature constant. The reactor was equipped with an ozone generator (Triogen LAB2B, Glasgow, UK), an external feed flow rate control device (Bronkhorst ${ }^{\circledR}$ EL-FLOW select F-201 CV /F-211 CV, Dutch, The Netherlands), and an ultrafine-bubble compressor (Fluid Metering, FMI Lab Model MA5S, Hack UFB Co., Ltd., Yamanashi, Japan) to provide the required ultrafine-bubble ozone gas, transferring into the solution as dissolved ozone for the degradation of tetracycline; the diameters of the ultrafine bubbles were $0.5-3 \mu \mathrm{m}$. The maximum $\mathrm{O}_{3}$ dosage produced was $10 \mathrm{~g} / \mathrm{h}$; as the ozone flow rates were maintained at 30 and $40 \mathrm{~mL} / \mathrm{min}$, the ozone production rates were 0.06 and $0.08 \mathrm{~g} \mathrm{O}_{3} / \mathrm{h}$, respectively. Several instruments (Eutech/CyberScan $\mathrm{pH}$ 510, Taiwan) were placed in the reactor to monitor parameters such as $\mathrm{pH}$, oxidation reduction potential (ORP) and dissolved oxygen (DO) concentration. The concentration of dissolved ozone $\left(\mathrm{DO}_{3}\right)$ was measured by the ozone monitor (Kasahara OZ-301, Gifu Prefecture, Japan) conducted with a thin film electrode method.

\subsection{Experimental Conditions}

Figure 2 shows profiles of dissolved ozone concentrations during ultrafine-bubble and milli-bubble ozonation with deionized water (DI water, produced by ultrapure water producer, ELGA option-Q, Taiwan), where the ozone flow rate was $40 \mathrm{~mL} / \mathrm{min}, \mathrm{pH}$ 6.5 and $25{ }^{\circ} \mathrm{C}$. After $60 \mathrm{~min}$ of milli-bubble ozonation, the dissolved ozone concentration reached $4.2 \mathrm{mg} / \mathrm{L}$. When ultrafine-bubble ozonation was used instead, the dissolved ozone concentration exceeded this level after just $2 \mathrm{~min}$ of ozonation. After $20 \mathrm{~min}$ of ozonation, the maximum dissolved ozone concentration reached $9.2 \mathrm{mg} / \mathrm{L}$, which demonstrates that a smaller size of the ozone gas bubbles is preferable to enhance the dissolved ozone concentration, which was integrated with respect to time to calculate the quantity of ozone produced, as shown in Figure 2. The grey area, which was calculated to be $484.2 \mathrm{mg} \cdot \mathrm{O}_{3} \mathrm{~min} / \mathrm{L}$, represents the real quantity of ozone present during the ozonation; in this study, the area was equivalent to $0.08 \mathrm{~g} \mathrm{O}_{3} / \mathrm{h}$. The initial concentration of tetracycline varied from 50 to $500 \mathrm{mg} / \mathrm{L}$. Other parameters such as $\mathrm{pH}$ levels (3-11), ozone dosages $(0.06-0.08 \mathrm{~g} / \mathrm{h})$, the addition of tert-butanol $(50-400 \mathrm{mg} / \mathrm{L})$, and temperatures $\left(15-55^{\circ} \mathrm{C}\right)$ were also systematically varied.

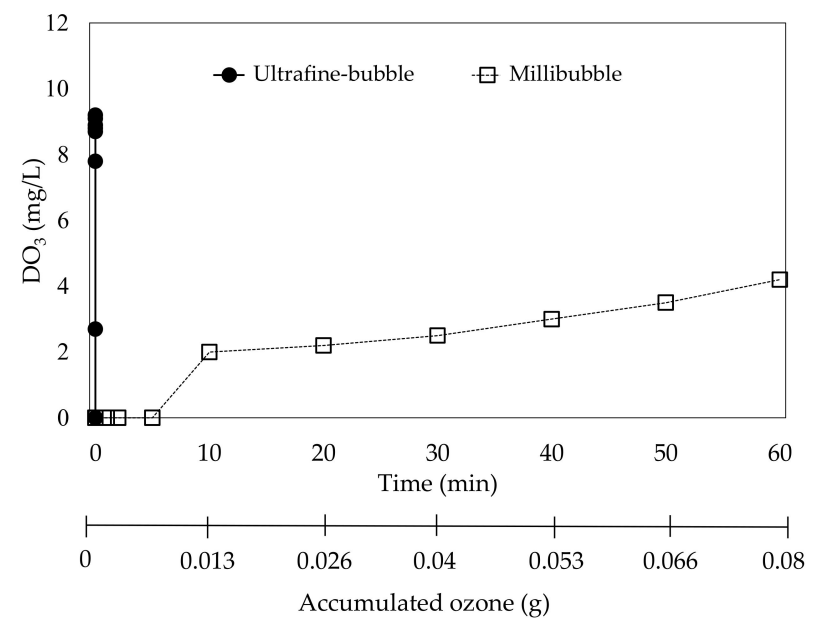

Figure 2. Concentration of dissolved ozone during ultrafine-bubble ozonation with deionized (DI) water (flow rate $40 \mathrm{~mL} / \mathrm{min}$; temperature $25^{\circ} \mathrm{C}$; $\mathrm{pH} 6.5$ ). 


\subsection{Sample Analysis}

A UV-visible spectrophotometer (Thermo Scientific GENESYS 10S, Madison, WI, USA) and a total organic carbon (TOC) analyzer (TOC-500, Shimadzu, Japan) were used to measure the concentration of tetracycline and TOC. Prior to measuring tetracycline concentration during the experiments, a calibration curve with satisfactory linear regression value was developed based on UV-Vis spectrophotometry. A full scan of UV-visible spectrophotometer indicated that two major absorption peaks were observed at wavelengths of 276 and $357 \mathrm{~nm}$ [25]. However, based on the literature, $357 \mathrm{~nm}$ was identified as the maximum absorption wavelength for the determination of tetracycline concentration [26,27]; the limit of quantification of tetracycline in this study was $0.024 \mathrm{mg} / \mathrm{L}$. Toxicity of the solution before and after ultrafine-bubble ozonation was determined as described in an earlier study [27]. In all figures, each experiment was carried out three times and the data shown in each curve were the averages.

\section{Results and Discussion}

\subsection{Effect of $p H$}

It is well-known that direct attack of organic molecules by mechanisms at acidic condition is the major reaction, and $\cdot \mathrm{OH}$ radicals oxidation mechanisms dominate the degradation of refractory organic pollutants at basic conditions [28]. In addition, tetracycline contains two acidic groups and one alkaline group so that there are four different species in the aqueous phase at different $\mathrm{pH}$ values [26], and these different $\mathrm{pH}$ values would induce the tetracycline oxidation to take place in different functional groups. In this study, the initial $\mathrm{pH}$ levels were varied from 3 to 11 to investigate the effect of $\mathrm{pH}$ on the degradation and mineralization of tetracycline. The profiles of the tetracycline residues during ultrafine-bubble ozonation are shown in Figure 3. The residual concentrations of tetracycline after $60 \mathrm{~min}^{\prime}$ reaction (accumulated ozone $=0.08 \mathrm{~g} \mathrm{O}_{3}$ ) at all $\mathrm{pH}$ levels were comparable, with values between 0.24 and $0.44 \mathrm{mg} / \mathrm{L}$, and the degradation percentages were all higher than $99 \%$. However, at low $\mathrm{pH}$, the degradation of tetracycline occurred within a reaction time of $20 \mathrm{~min}\left(0.026 \mathrm{~g} \mathrm{O}_{3}\right)$, which indicates that lower $\mathrm{pH}$ assists tetracycline degradation, due to a cationic tetracycline species observed in aqueous solution, and the oxidization potentials of $\cdot \mathrm{OH}$ radicals are higher in acidic medium than in basic medium [26-29]. Besides the type of tetracycline presented in solution, the concentration of dissolved ozone may be the key parameter affecting the degradation of tetracycline. Figure 4a shows that at $\mathrm{pH} 3$, no dissolved ozone was detected for the first $10 \mathrm{~min}$. The dissolved ozone concentration then increased to $7.8 \mathrm{mg} \mathrm{O}_{3} / \mathrm{L}$ by the end of the reaction. At $\mathrm{pH} 11$, the concentration of dissolved ozone was still zero after $20 \mathrm{~min}$ ' reaction, after which it steadily increased to $6.3 \mathrm{mg} / \mathrm{L}$ (Figure $4 \mathrm{~b}$ ). Based on the integration, the grey areas in Figure $4 \mathrm{a}, \mathrm{b}$ were 289.2 and 364.2 , respectively, which estimates that the consumption of dissolved ozone for tetracycline degradation is equivalent to $0.048 \mathrm{~g} \mathrm{O}_{3}$ and $0.060 \mathrm{~g} \mathrm{O}_{3}$ at $\mathrm{pH}$ 3 and $\mathrm{pH} 11$; this indicates that each gram of $\mathrm{O}_{3}$ can degrade $1.041 \mathrm{~g}$ and 0.833 tetracycline, respectively. However, as the results show in Figure 3, $20 \mathrm{~min}$ of ultrafine-bubble ozonation was adequate to degrade most tetracycline at $\mathrm{pH} 3$ to $\mathrm{pH}$ 9, which indicated that the required ozone dosage was $0.018 \mathrm{~g} \mathrm{O}_{3}$ (grey area was 108) to degrade $49 \mathrm{mg} / \mathrm{L}$ tetracycline. Hence, at those conditions, each gram of ozone could degrade $2.72 \mathrm{~g}$ tetracycline. At $\mathrm{pH}$ 11, ultrafine-bubble ozonation should be carried out for at least $30 \mathrm{~min}$ to degrade $49 \mathrm{mg} / \mathrm{L}$ tetracycline, which indicated that the required ozone dosage was $0.033 \mathrm{~g} \mathrm{O}_{3}$ (grey area was 199) and each gram ozone could degrade $1.48 \mathrm{~g}$ of tetracycline. 


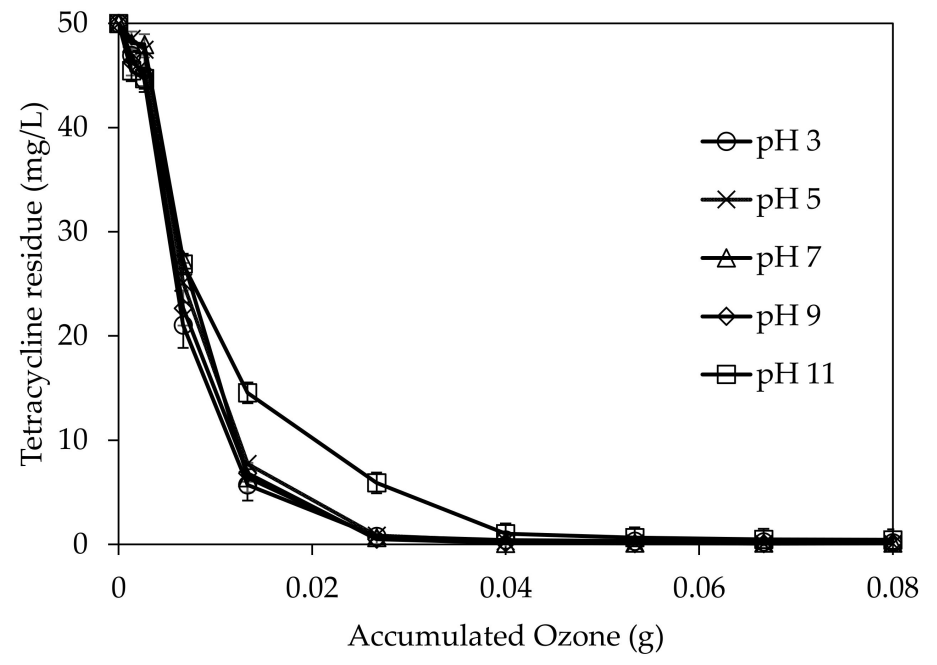

Figure 3. Residual tetracycline in solution during ultrafine-bubble ozonation at different $\mathrm{pH}$ levels.

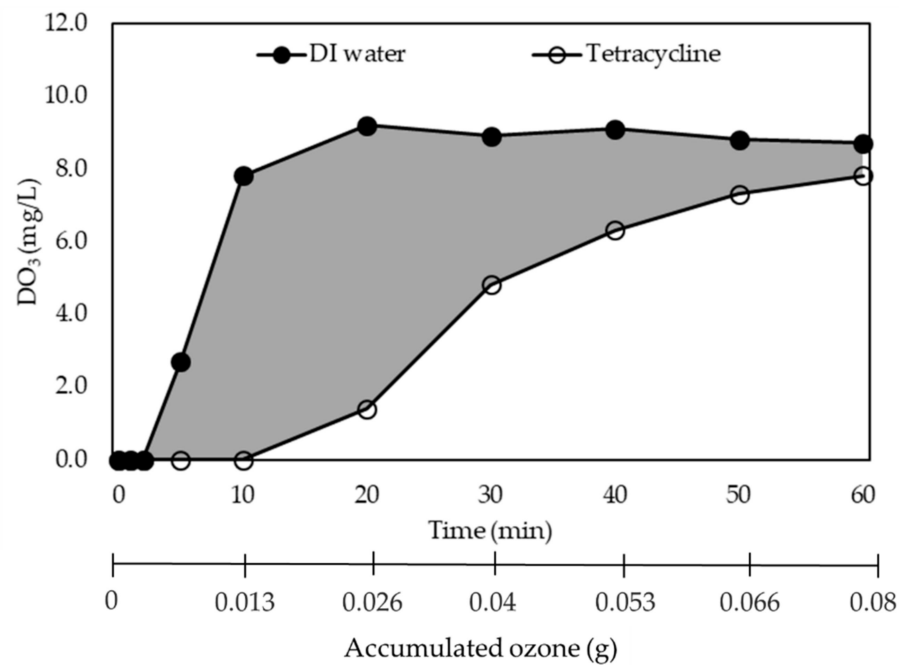

(a)

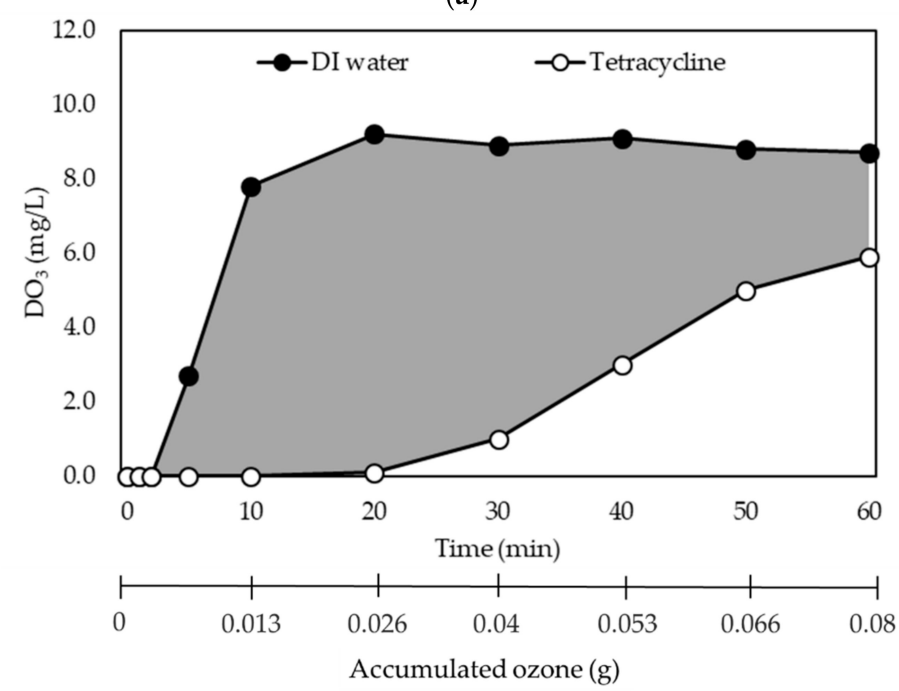

(b)

Figure 4. Ozone usage during tetracycline degradation calculated by integrating method at (a) $\mathrm{pH} 3$ and (b) $\mathrm{pH} 11$. 
As the tetracycline was degraded by the introduction of ozone gas bubbles, it reacted with ozone molecules or $\cdot \mathrm{OH}$ to form intermediates, then become further oxidized and mineralized to $\mathrm{CO}_{2}$ and $\mathrm{H}_{2} \mathrm{O}$, as shown as Equations (4) and (5). Therefore, it is estimated that the reaction rate can be obtained from the calculation of tetracycline concentration and ozone (or $\cdot \mathrm{OH})$ concentration, based on Equations (6) and (7), where the reaction kinetics should be defined as a second-order type. However, the ozone gas is continuously introduced into the reactor and then the concentration of ozone reaches a stable level, so that the ozone or $\cdot \mathrm{OH}$ concentration in the solution phase may be considered at a consistent stage. Then the calculation of rate constant can be achieved by pseudo first-order kinetics, based on Equation (8). Table 1 shows the tetracycline degradation percentages, the pseudo first-order rate constants for tetracycline degradation (reaction time was $60 \mathrm{~min}$ ), mineralization of tetracycline (presented as TOC removal), and toxicity (presented as cell viability) at different reaction conditions. The pseudo first-order rate constant at $\mathrm{pH} 3$ was greater than other $\mathrm{pH}$ levels, which indicates that the degradation of tetracycline at this $\mathrm{pH}$ level was fastest, though the final degradation efficiencies at all five $\mathrm{pH}$ levels were comparable. However, the levels of mineralization of tetracycline at basic $\mathrm{pH}$ levels were higher than those at acidic levels; this corresponds with Figure $4 \mathrm{~b}$ in that the higher dose of ozone was used in the further degradation of organic compounds into $\mathrm{CO}_{2}$ [30]. The cell viability at $\mathrm{pH} 11$ was higher than at other $\mathrm{pH}$ levels, which indicates that the toxicity of the solution at $\mathrm{pH} 11$ had been reduced sufficiently by the higher mineralization of the organic compounds [28-31].

$$
\begin{gathered}
\text { Tetracycline }+\mathrm{O}_{3} \rightarrow \text { Intermediates } \rightarrow \mathrm{CO}_{2}+\mathrm{H}_{2} \mathrm{O} \\
\text { Tetracycline }+\cdot \mathrm{OH} \rightarrow \text { Intermediates } \rightarrow \mathrm{CO}_{2}+\mathrm{H}_{2} \mathrm{O} \\
\text { Rate }=\mathrm{k} \times[\text { Tetracycline }] \times\left[\mathrm{O}_{3}\right] \\
\text { Rate }=\mathrm{k} \times[\text { Tetracycline }] \times[\cdot \mathrm{OH}] \\
\text { Rate }=\mathrm{k}^{\prime} \times[\text { Tetracycline }]
\end{gathered}
$$

Table 1. Degradation and mineralization of tetracycline by ultrafine-bubble ozonation at different reaction $\mathrm{pH}$ and temperatures.

\begin{tabular}{ccccccc}
\hline $\begin{array}{c}\text { Concentration } \\
\text { of Tetracycline } \\
(\mathbf{m g} / \mathbf{L})\end{array}$ & $\mathbf{p H}$ & $\begin{array}{c}\text { Temperature } \\
\mathbf{(} \mathbf{C})\end{array}$ & $\begin{array}{c}\text { Degradation } \\
\text { Efficiency of } \\
\text { Tetracycline } \\
\mathbf{( \% )}\end{array}$ & $\begin{array}{c}\text { Mineralization } \\
\text { Efficiency of } \\
\text { Tetracycline } \\
\mathbf{( \% )}\end{array}$ & $\begin{array}{c}\text { Pseudo First-order } \\
\text { Degradation Kinetic } \\
\text { Rate }\left(\mathbf{m i n}^{-\mathbf{1})}\right.\end{array}$ & $\begin{array}{c}\text { Cell Viability } \\
\mathbf{( \% )}\end{array}$ \\
\hline 50 & 3 & 25 & 99.6 & 19.1 & 0.121 & $66.3 \pm 14.5$ \\
50 & 5 & 25 & 99.8 & 20.7 & 0.119 & $67.6 \pm 18.2$ \\
50 & 7 & 25 & 99.8 & 22.2 & 0.117 & $71.1 \pm 18.1$ \\
50 & 9 & 25 & 99.7 & 24.6 & 0.112 & $74.7 \pm 15.8$ \\
50 & 11 & 25 & 99.1 & 31.9 & 0.088 & $84.3 \pm 13.5$ \\
\hline 50 & 3 & 15 & 99.7 & 11.3 & 0.122 & $62.2 \pm 10.8$ \\
50 & 3 & 25 & 99.6 & 19.1 & 0.121 & $66.3 \pm 14.5$ \\
50 & 3 & 35 & 99.6 & 25.2 & 0.119 & $76.5 \pm 23.5$ \\
50 & 3 & 45 & 99.7 & 29.5 & 0.116 & $82.9 \pm 21.2$ \\
50 & 3 & 55 & 99.5 & 36.2 & 0.115 & $87.5 \pm 15.0$ \\
\hline
\end{tabular}

${ }^{*}$ Cell viability of a blank sample (DI water) was $100 \%$.

\subsection{Effect of Temperature}

Several parameters of reaction mechanisms involving ozone, such as Brown hydrogenation of organic compounds by ozone, mass transfer coefficients, and ozone gas solubility, are temperature-dependent [32,33]. As the mass transfer to the solution or the ozone gas solubility increases, the degradation of organic compounds is enhanced. Five reaction temperatures were used to investigate the effect of temperature on ultrafine-bubble 
ozonation, and the results are also shown in Table 1 . The degradation of tetracycline after 60 min was approximately $99.5 \%$ at all five temperatures.

Though temperature had little effect on the degradation of tetracycline, the rate of TOC removal and change in cell viability were both affected. Increasing the reaction temperature increased the TOC removal and cell viability, which demonstrates that higher reaction temperatures resulted in the conversion of organic molecules to $\mathrm{CO}_{2}$, thus reducing the toxicity of the solution. This is explained by the increased reactivity between organic compounds and ozone at higher temperatures $[5,34]$. However, lower reaction temperatures increase the solubility of ozone and the mass transfer of ozone from the gas to the solution phase [32-35]. This explains why, in Figure 5, the residual tetracycline concentration after ten minutes' reaction at $15^{\circ} \mathrm{C}$ was lower than at $55^{\circ} \mathrm{C}$. The degradation rate was slightly faster at lower solution temperatures because of the higher dissolved ozone concentration. In fact, only $20 \mathrm{~min}^{\prime}$ reaction was needed to achieve this high treatment performance. The ultrafine-bubble ozonation method effectively degrades tetracycline regardless of the reaction temperature, so controlling the reaction temperature need not be prioritized.

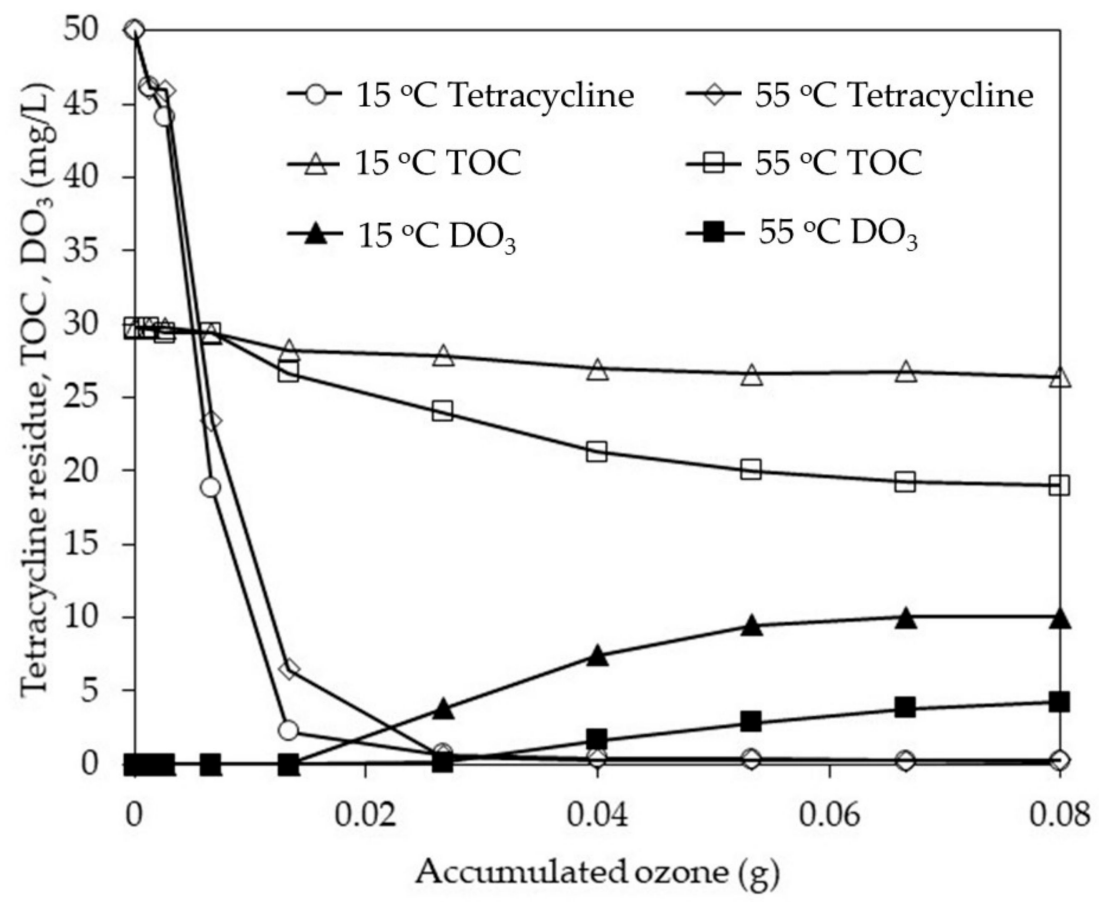

Figure 5. Residual tetracycline and total organic carbon (TOC) in solution during ultrafine-bubble ozonation at different reaction temperatures.

\subsection{Effect of Tetracycline Concentration}

Almost $100 \%$ of the tetracycline was degraded within $20 \mathrm{~min}$ ' reaction when the initial tetracycline concentration was $50 \mathrm{mg} / \mathrm{L}$ (Figure 5). This suggests that ultrafine-bubble ozonation with $0.08 \mathrm{~g}$ of accumulated ozone can degrade more tetracycline than $50 \mathrm{mg} / \mathrm{L}$. Hence, four different initial tetracycline concentrations, 50, 100, 200, and $500 \mathrm{mg} / \mathrm{L}$, were carried out for ultrafine-bubble ozonation, and the results are shown in Table 2 and Figure 6. More than $90 \%$ of the tetracycline was degraded even when the initial tetracycline concentration was as high as $500 \mathrm{mg} / \mathrm{L}$. The exact amount of tetracycline removed by $60 \mathrm{~min}^{\prime}$ reaction was $454 \mathrm{mg}$. In addition, dissolved ozone was not detected in solution during the 60 min reaction, which indicated that the introduced ozone was fully used to degrade tetracycline. This can be explained by the fact that increasing tetracycline initial concentration causes an increase in the concentration of degradation intermediates and, as a result, extra ozone consumption for increased removal and oxidation of by-products [36]. Therefore, even though the pseudo first-order rate constant at $500 \mathrm{mg} / \mathrm{L}$ tetracycline solution was much lower than at the other concentrations, the tetracycline removal rate was still 
high enough to suggest that the technology is effective even at high initial tetracycline concentrations. As the initial concentration of tetracycline increased, the amount of carbon present in the solution also increased. More dissolved ozone was therefore consumed in the degradation and mineralization of the organic compounds. Hence, in Figure 6, residual dissolved ozone concentration and the TOC removal ratio both decreased as the initial concentration of tetracycline increased. The cell viability also decreased because fewer tetracycline molecules were fully decomposed [35-37]. This suggests that the ozone dosage (or gas flow rate) should be augmented for the treatment of solutions with higher initial tetracycline concentrations. However, based on the results of ozone usage and tetracycline degradation, it is found in Table 2 that each gram of $\mathrm{O}_{3}$ could degrade 2.54 to $5.68 \mathrm{~g}$ of tetracycline. This indicates that ultrafine-bubble ozonation with an accumulated ozone of $0.08 \mathrm{~g}$ can not only be used to degrade lower concentrations of tetracycline solution but also to degrade very high concentration solutions.

Table 2. Degradation and mineralization of tetracycline by ultrafine-bubble ozonation at different initial tetracycline concentrations ( $\mathrm{pH} 3$, temp. $\left.25^{\circ} \mathrm{C}\right)$.

\begin{tabular}{|c|c|c|c|c|c|}
\hline $\begin{array}{c}\text { Concentration } \\
\text { of Tetracycline } \\
(\mathrm{mg} / \mathrm{L})\end{array}$ & $\begin{array}{c}\text { Degradation } \\
\text { Efficiency of } \\
\text { Tetracycline (\%) }\end{array}$ & $\begin{array}{l}\text { Mineralization } \\
\text { Efficiency of } \\
\text { Tetracycline }(\%)\end{array}$ & $\begin{array}{c}\text { Degradation of } \\
\text { Tetracycline by Each } \\
\text { Gram of } \mathrm{O}_{3} \\
\text { (g Tetracycline/g O } \mathrm{O}_{3} \text { ) }\end{array}$ & $\begin{array}{l}\text { Pseudo First-Order } \\
\text { Degradation Kinetic } \\
\text { Rate }\left(\mathrm{min}^{-1}\right)\end{array}$ & $\begin{array}{l}\text { Cell } \\
\text { Viability } \\
(\%) *\end{array}$ \\
\hline 50 & 99.7 & 19.1 & 2.72 & 0.121 & $66.3 \pm 14.5$ \\
\hline 100 & 98.6 & 16.1 & 2.90 & 0.098 & $65.1 \pm 7.9$ \\
\hline 200 & 99.1 & 14.8 & 2.54 & 0.074 & $62.9 \pm 5.8$ \\
\hline 500 & 90.8 & 2.9 & 5.68 & 0.043 & $57.6 \pm 11.7$ \\
\hline
\end{tabular}

* Cell viability of a blank sample (DI water) was $100 \%$.

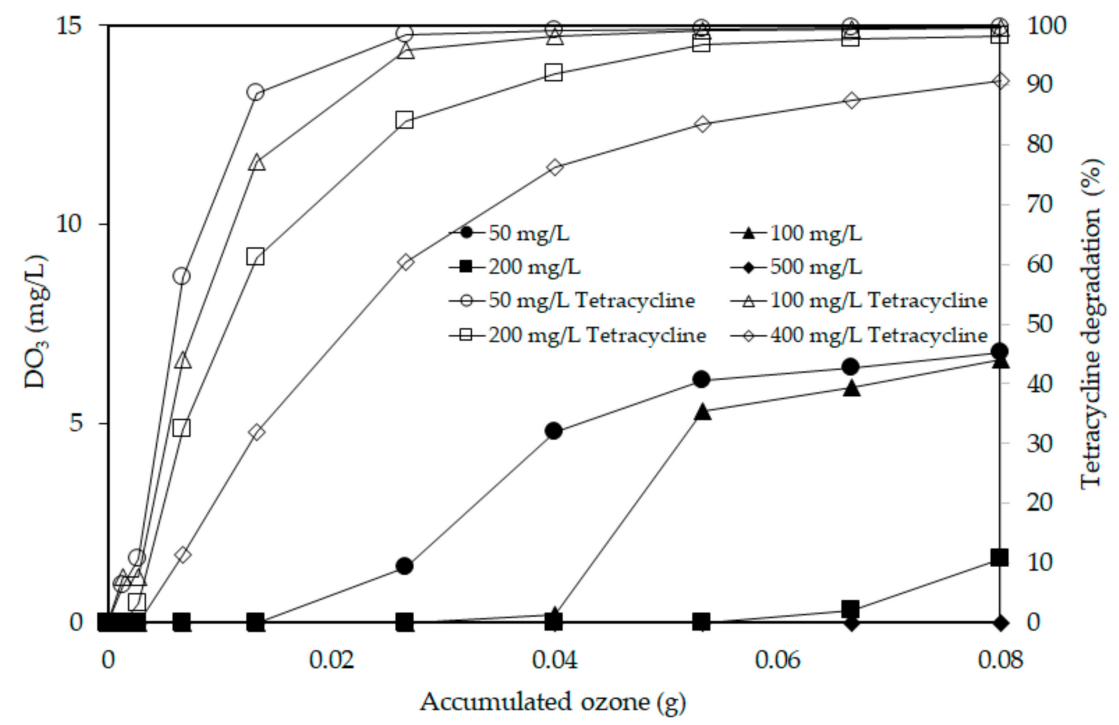

Figure 6. Tetracycline degradation percentage and dissolved ozone concentration during ultrafinebubble ozonation at different initial tetracycline concentrations.

\subsection{Toxicity Profiles}

Although ultrafine-bubble ozonation effectively degraded tetracycline with a maximum TOC removal rate of $36.2 \%$, more than $60 \%$ of the degraded tetracycline was not mineralized to $\mathrm{CO}_{2}$ by the oxidation process. The toxicity of tetracycline and its degradation by-products of environmentally relevant bacteria was investigated and found that the minimum inhibitory concentration of tetracycline was $2.0 \mathrm{mg} / \mathrm{L}$, much lower than most tetracycline degradation by-products [38]. However, even tetracycline might be degraded as a by-product by oxidation methods, the possible by-products still contained four aro- 
matic rings in the molecular structures. Hence, full mineralization should be considered as the priority. Changes in the toxicity of the solution based on cell viability measurements must also be evaluated along with the degradation efficiencies. Twelve experimental runs were carried out (Tables 1 and 2), and the rate of TOC removal is plotted against cell viability in Figure 7. Prior to degradation, the cell viability of untreated $50 \mathrm{mg} / \mathrm{L}$ tetracycline was $55.3 \% \pm 11.6 \%$, while the cell viability of a blank sample (DI water) was $100 \%$. The TOC removal rate was strongly correlated with the cell viability $\left(R^{2}=0.94\right)$, which indicates that the higher mineralization of tetracycline decreased the toxicity of the solution. This demonstrates that TOC removal during the degradation of organic compounds is the critical factor in reducing toxicity [30]. After the toxicity of tetracycline is reduced by the oxidation process, the wastewater should be subjected to further biological treatments to reduce the concentrations of other chemicals.

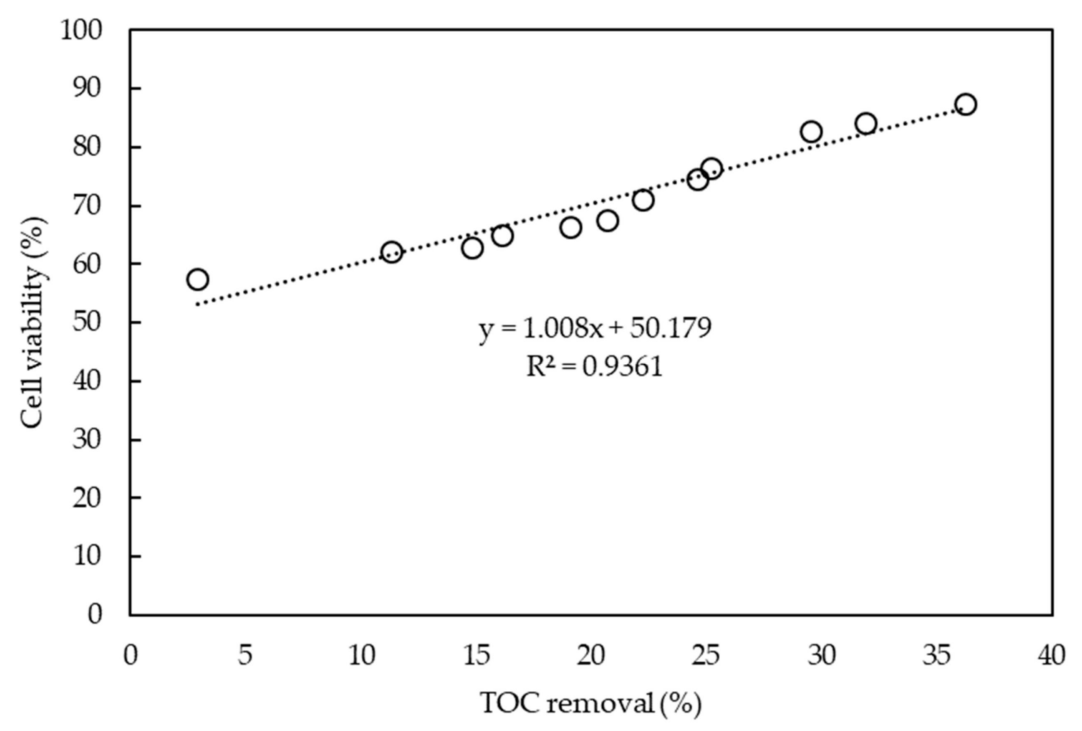

Figure 7. Correlation between cell viability and TOC removal in the tetracycline degradation tests.

In Table 3, the effect of ozone dosage and tert-butanol addition, which is a well-known . $\mathrm{OH}$ radical scavenger, on the degradation of tetracycline was investigated. It is shown in Table 3 that increasing the dosage of ozone profits the degradation and mineralization of tetracycline. Even though the results of tetracycline degradation after 60 min reaction are comparable, as the ozone dosages are 0.06 and $0.08 \mathrm{~g} \mathrm{O}_{3} / \mathrm{L}$, it is still different in the first $10 \mathrm{~min}$, where the degradation results are $80 \%$ and $90 \%$, respectively. This result proves that tetracycline can be degraded quicker with higher ozone dosages. Not only the results of tetracycline degradation but also tetracycline mineralization, increase of cell viability, and reaction rate constant show that higher ozone dosages are useful to increase the reactivity of tetracycline treatment. In previous observations, it is known that the reaction between organic compounds and $\cdot \mathrm{OH}$ radicals predominate in the mineralization mechanism of tetracycline. Therefore, in this study, four different concentrations of tertbutanol, which has been generally used as an $\cdot \mathrm{OH}$ radicals scavenger, were added in the solution to investigate the effect. It is found that the degradation efficiencies at different tert-butanol additions are similar, but mineralization is found to slightly decrease with increasing tert-butanol additions. It is a fact that degradation of tetracycline is mainly contributed to by ozone molecule direct oxidation, so that even the addition of tert-butanol will scavenge the formation of $\cdot \mathrm{OH}$ radicals, with degradation of tetracycline comparable to the data without tert-butanol addition. In addition, mineralization of tetracycline is influenced by tert-butanol addition, where the higher addition of tert-butanol led to lower mineralization results. 
Table 3. Degradation and mineralization of tetracycline by ultrafine-bubble ozonation at different ozone dosages and tert-butanol additions.

\begin{tabular}{cccccc}
\hline $\begin{array}{c}\text { Dosage of Ozone } \\
(\mathbf{g})\end{array}$ & $\begin{array}{c}\text { Addition of } \\
\text { tert-Butanol } \\
(\mathbf{m g} / \mathbf{L})\end{array}$ & $\begin{array}{c}\text { Degradation } \\
\text { Efficiency of } \\
\text { Tetracycline (\%) }\end{array}$ & $\begin{array}{c}\text { Mineralization } \\
\text { Efficiency of } \\
\text { Tetracycline (\%) }\end{array}$ & $\begin{array}{c}\text { Pseudo First-Order } \\
\text { Degradation Kinetic } \\
\text { Rate (min-1) }\end{array}$ & $\begin{array}{c}\text { Cell } \\
\text { Viability } \\
(\%)\end{array}$ \\
\hline 0.06 & - & 99.3 & 14.5 & 0.113 & $60.9 \pm 11.2$ \\
0.08 & - & 99.6 & 19.1 & 0.121 & $66.3 \pm 14.5$ \\
\hline 0.08 & 50 & 99.7 & 7.9 & 0.121 & 6.122 \\
0.08 & 100 & 99.8 & 7.6 & 0.119 & $68.6 \pm 7.6$ \\
0.08 & 200 & 99.7 & 7.1 & 0.119 & $73.3 \pm 11.7$ \\
0.08 & 400 & 99.6 & 6.5 & & $74.5 \pm 22.8$ \\
\hline
\end{tabular}

${ }^{*}$ Cell viability of a blank sample (DI water) was $100 \%$.

\subsection{Operational Cost}

The operational costs of several oxidation processes for degrading tetracycline, such as ultrasound, Fenton reactions, milli-bubble ozonation, and their combinations, have been proposed [27], and the results are shown in Table 4 (items g to j). It is found in Table 4 that the operational costs of ultrasound and the Fenton process applied individually were 2466.53 USD and 263.76 USD, respectively, to remove $1 \mathrm{~kg}$ of tetracycline from solution (i.e., if the tetracycline concentration is $50 \mathrm{mg} / \mathrm{L}$, removing $1 \mathrm{~kg}$ of tetracycline equates to treating $20 \mathrm{~m}^{3}$ of wastewater). When ultrasound was combined with the Fenton process (a sono-Fenton system), the costs of the chemical reagents (Fenton) and electricity charges (sonicator) led to a higher operational cost of 393.20 USD per kg of tetracycline removed. When the milli-bubble ozonation was used either as the sole process in the treatment or in combination with other processes, the operational costs to remove $1 \mathrm{~kg}$ of tetracycline were 193.63-405.59 USD. The operational costs for $\mathrm{O}_{3}+$ Fenton and $\mathrm{O}_{3}+$ sono-Fenton processes were lower than the Fenton process alone because of the shorter reaction times. In this study, we used an ultrafine-bubble compressor to reduce the bubble size and increase the solubility of various gases for the treatment of tetracycline. When the air was used, the operational costs were much higher than for oxygen or ozone, even though the only cost was that of electricity for the pump and compressor. This was because of the extremely low degradation efficiency of tetracycline after $60 \mathrm{~min}^{\prime}$ treatment with air.

Table 4. Degradation and mineralization of tetracycline by ultrafine-bubble ozonation at different reaction conditions.

\begin{tabular}{|c|c|c|c|c|}
\hline \multirow[t]{2}{*}{ Methods } & $\begin{array}{l}\text { Tetracycline } \\
\text { Removal }\end{array}$ & $\begin{array}{l}\text { Tetracycline } \\
\text { Concentration }\end{array}$ & $\begin{array}{c}\text { Operational } \\
\text { Cost }\end{array}$ & Operational Cost \\
\hline & Percentage $(\%)$ & $(\mathrm{mg} / \mathrm{L})$ & (USD/run) & (USD/kg Tetracycline Removal) \\
\hline \multicolumn{5}{|l|}{ Ultra-fine bubbles ozonation } \\
\hline $50 \mathrm{mg} / \mathrm{L}^{\mathrm{a}}$ & 98.5 & 50 & 0.185 & 125.27 \\
\hline $100 \mathrm{mg} / \mathrm{L}^{\mathrm{b}}$ & 98.3 & 100 & 0.278 & 94.13 \\
\hline $200 \mathrm{mg} / \mathrm{L}^{\mathrm{c}}$ & 98.3 & 200 & 0.555 & 94.11 \\
\hline $500 \mathrm{mg} / \mathrm{L}^{\mathrm{d}}$ & 90.8 & 500 & 0.555 & 40.77 \\
\hline Oxygen ${ }^{\mathrm{e}}$ & 3.0 & 50 & 0.250 & 551.88 \\
\hline Air ${ }^{f}$ & 0.6 & 50 & 0.014 & 1555.57 \\
\hline Milli-bubble $\mathrm{O}_{3} \mathrm{~g}$ & 98.0 & 50 & 0.539 & 330.06 \\
\hline Milli-bubble $\mathrm{O}_{3}+$ Ultrasound ${ }^{\mathrm{h}}$ & 98.0 & 50 & 0.655 & 405.59 \\
\hline Milli-bubble $\mathrm{O}_{3}+$ Fenton $^{\mathrm{i}}$ & 98.0 & 50 & 0.313 & 193.63 \\
\hline Milli-bubble $\mathrm{O}_{3}+$ ultrasound + Fenton $^{\mathrm{j}}$ & 99.8 & 50 & 0.371 & 229.71 \\
\hline
\end{tabular}

${ }^{\mathrm{a}} \mathrm{O}_{3}=0.04 \mathrm{~L} / \mathrm{min}, \mathrm{pH} \mathrm{3,} 20 \mathrm{~min} ;{ }^{\mathrm{b}} \mathrm{O}_{3}=0.04 \mathrm{~L} / \mathrm{min}, \mathrm{pH} \mathrm{3,} 30 \mathrm{~min} ;{ }^{\mathrm{c}} \mathrm{O}_{3}=0.04 \mathrm{~L} / \mathrm{min}, \mathrm{pH} 3,60 \mathrm{~min} ;{ }^{\mathrm{d}} \mathrm{O}_{3}=0.04 \mathrm{~L} / \mathrm{min}, \mathrm{pH} 3,60 \mathrm{~min}$; ${ }^{\mathrm{e}} \mathrm{O}_{2}=0.04 \mathrm{~L} / \mathrm{min}, 60 \mathrm{~min} ;{ }^{\mathrm{f}} \mathrm{Air}=0.04 \mathrm{~L} / \mathrm{min}, 60 \mathrm{~min} ;{ }^{\mathrm{g}} \mathrm{O}_{3}=0.2 \mathrm{~L} / \mathrm{min}, 55^{\circ} \mathrm{C}, \mathrm{pH} 3,20 \mathrm{~min} ;{ }^{\mathrm{h}} \mathrm{O}_{3}=0.2 \mathrm{~L} / \mathrm{min}$, ultrasonic watts $100 \mathrm{~W}$, $55^{\circ} \mathrm{C}, \mathrm{pH} 3,20 \mathrm{~min} ;{ }^{\mathrm{i}} \mathrm{O}_{3}=0.2 \mathrm{~L} / \mathrm{min}, \mathrm{Fe}^{2+}=0.2 \mathrm{mM}, \mathrm{H}_{2} \mathrm{O}_{2}=2 \mathrm{mM}, 55^{\circ} \mathrm{C}, \mathrm{pH} 3,10 \mathrm{~min} ;{ }^{\mathrm{j}} \mathrm{O}_{3}=0.2 \mathrm{~L} / \mathrm{min}, \mathrm{Fe}^{2+}=0.2 \mathrm{mM}, \mathrm{H}_{2} \mathrm{O}_{2}=2 \mathrm{mM}$, ultrasonic watts $100 \mathrm{~W}, 55^{\circ} \mathrm{C}, \mathrm{pH} 3,10 \mathrm{~min}$.

Table 4 also shows that the treatment performances of milli-bubble ozonation $(200 \mathrm{~mL}$ $\left.\mathrm{O}_{3} / \mathrm{min}\right)$ and ultrafine-bubble ozonation $\left(40 \mathrm{~mL} \mathrm{O}_{3} / \mathrm{min}\right)$ were comparable. With $20 \mathrm{~min}^{\prime}$ 
treatment, the degradation efficiencies of both processes were greater than $98 \%$. Decreasing the bubble size increased the reactivity of ozone with organic compounds, allowing the ultrafine-bubble ozonation to achieve satisfactory treatment performance with lower gas flows or ozone dosages. In addition, the operational cost for ultrafine-bubble ozonation shown in Table 4 is only $38 \%$ of the milli-bubble ozonation operational cost. The operational costs for treating higher initial tetracycline concentrations were also lower: $100 \mathrm{mg} / \mathrm{L}$ tetracycline solution was treated for $30 \mathrm{~min}$ with ultrafine-bubble ozonation, resulting in $98.3 \%$ tetracycline degradation at a cost of 94.13 USD per kg of tetracycline; for $500 \mathrm{mg} / \mathrm{L}$ tetracycline solution, $90.8 \%$ degradation was achieved in $60 \mathrm{~min}$ reaction at a cost per kilogram of tetracycline ( $20 \mathrm{~m} 3$ tetracycline wastewater) as low as 40.77 USD. This demonstrates that $40 \mathrm{~mL} / \mathrm{min}$ ultrafine-bubble ozonation has sufficient oxidation performance to degrade solutions with high tetracycline concentrations. In this study, we used a commercial pure oxygen steel cylinder to supply oxygen to the ozone gas producer. The unit price of pure oxygen was about 3.6 times the unit price of air (Table 4), so the operational costs will be lower still if air can be used instead of oxygen to generate ozone.

\section{Conclusions}

The performance of tetracycline degradation and detoxification by an ultrafine-bubble compressor equipped with an ozone gas producer was found to be effective, where each gram of ozone could degrade as high as $5.68 \mathrm{~g}$ tetracycline if the initial tetracycline concentration was $500 \mathrm{mg} / \mathrm{L}$. The decrease in solution toxicity was due to the removal of TOC or the mineralization of organic compounds. The results of rate constant indicated that the degradation of tetracycline was faster at acidic solution than that at basic ones. In addition, within the short treatment period, the tetracycline degradation capacity at $\mathrm{pH} 3$ was 1.84 times that at $\mathrm{pH} 11$. The effect of $\cdot \mathrm{OH}$ radicals scavenger by adding tert-butanol and higher reaction temperatures on tetracycline degradation can be neglected at acidic conditions, which indicates that the major reaction oxidation mechanism is the ozone molecule attack. Alkaline condition leads to the increase of tetracycline mineralization because of the higher concentrations of $\cdot \mathrm{OH}$ radicals contributing to the removal of TOC. The results of operational cost in this study indicate that the ultrafine-bubble ozonation process is cheaper than other processes and can be used to effectively degrade tetracycline and reduce its toxicity, even if the initial tetracycline concentration is as high as $500 \mathrm{mg} / \mathrm{L}$.

Author Contributions: Conceptualization, C.W.; methodology, C.W.; formal analysis, G.-Y.L. (GuanYun Liao); investigation, G.-Y.L. (Guan-Yun Liao); resources, C.W.; data curation, C.W.; writingoriginal draft preparation, G.-Y.L. (Guan-Yun Liao); writing-review and editing, C.W. and C.-Y.L. (Chien-Yu Lin); supervision, C.-Y.L. (Chien-Yu Lin); project administration, C.W.; funding acquisition, C.W. All authors have read and agreed to the published version of the manuscript.

Funding: This research was funded by the National Science Council, Republic of China, grant number 101-2221-E-264-005, and Ministry of Science and Technology, Republic of China, grant number 103-2221-E-264-001-MY2.

Institutional Review Board Statement: Not applicable.

Informed Consent Statement: Informed consent was obtained from all subjects involved in the study.

Data Availability Statement: Data is contained within the article.

Conflicts of Interest: The authors declare no conflict of interest.

\section{References}

1. Rodriguez-Mozaz, S.; Chamorro, S.; Marti, E.; Huerta, B.; Gros, M.; Sanchez-Melsio, A.; Borrego, C.M.; Barcelo, D.; Balcazar, J.L. Occurrence, of antibiotics and antibiotic resistance genes in hospital and urban wastewaters and their impact on the receiving river. Water Res. 2015, 69, 234-242. [CrossRef]

2. Bartrons, M.; Peñuelas, J. Pharmaceuticals, and personal-care products in plants. Trends Plant Sci. 2017, 22, 194-203. [CrossRef] [PubMed] 
3. Cui, D.; Liu, X.; Hawkey, P.; Li, H.; Wang, Q.; Mao, Z.; Sun, J. Use, of and microbial resistance to antibiotics in China: A path to reducing antimicrobial resistance. J. Int. Med. Res. 2017, 45, 1768-1778. [CrossRef]

4. Tao, W.C.; Hsu, B.M.; Ji, W.T.; Hsu, T.K.; Kao, P.M.; Hsu, C.P.; Shen, S.M.; Shen, T.Y.; Wan, T.J.; Huang, Y.L. Evaluation, of five antibiotic resistance genes in wastewater treatment systems of swine farms by real-time PCR. Sci. Total Environ. 2014, 495, 116-121. [CrossRef] [PubMed]

5. Hu, E.; Wu, X.; Shang, S.; Tao, X.M.; Jiang, S.X.; Gan, L. Catalytic, ozonation of simulated textile dyeing wastewater using mesoporous carbon aerogel supported copper oxide catalyst. J. Clean. Prod. 2016, 112, 4710-4718. [CrossRef]

6. Chopra, I.; Roberts, M. Tetracycline, antibiotics: Mode of action, applications, molecular biology, and epidemiology of bacterial resistance. Microbiol. Mol. Biol. Rev. 2001, 65, 232-260. [CrossRef]

7. Roberts, C.M.; Schwarz, S. Tetracycline, and phenicol resistance genes and mechanisms: Importance for agriculture, the environment, and humans. J. Environ. Qual. 2016, 45, 576-592. [CrossRef]

8. Wu, J.; Zhang, H.; Oturan, N.; Wang, Y.; Chen, L.; Oturan, M.A. Application, of response surface methodology to the removal of the antibiotic tetracycline by electrochemical process using carbon-felt cathode and DSA $\left(\mathrm{Ti} / \mathrm{RuO}_{2}-\mathrm{IrO}_{2}\right)$ anode. Chemosphere 2012, 87, 614-620. [CrossRef]

9. Graham, G.G.; Pile, D.K. Tetracyclines. In Compendium of Inflammatory Diseases; Parnham, M.J., Ed.; Springer: Berlin, Germany, 2016; pp. 1231-1236.

10. Kładna, A.; Kruk, I.; Michalska, T.; Berczyński, P.; Aboul-Enein, H.Y. Characterization, of the superoxide anion radical scavenging activity by tetracycline antibiotics in aprotic media. Luminescence 2011, 26, 611-615. [CrossRef]

11. Oppenländer, T. Photochemical, Purification of Water and Air: Advanced Oxidation Processes (AOPs)-Principles, Reaction Mechanisms, Reactor Concepts; John Wiley \& Sons: Hoboken, NJ, USA, 2003; Volume 30.

12. Nidheesh, V.P.; Zhou, M.; Oturan, M.A. An, overview on the removal of synthetic dyes from water by electrochemical advanced oxidation processes. Chemosphere 2018, 197, 210-227. [CrossRef] [PubMed]

13. Cheng, M.; Zeng, G.; Huang, D.; Lai, C.; Xu, P.; Zhang, C.; Liu, Y. Hydroxyl, radicals based advanced oxidation processes (AOPs) for remediation of soils contaminated with organic compounds: A review. Chem. Eng. J. 2016, 284, 582-598. [CrossRef]

14. Kurt, A.; Mert, B.K.; Özengin, N.; Sivrioğlu, Ö.; Yonar, T. Treatment, of Antibiotics in Wastewater Using Advanced Oxidation Processes (AOPs). In Physico-Chemical Wastewater Treatment and Resource Recovery; IntechOpen: London, UK, 2017 ; Chapter 9. [CrossRef]

15. Alver, A.; Kılıç, A. Catalytic, ozonation by iron coated pumice for the degradation of natural organic matters. Catalysts 2018, 8, 219. [CrossRef]

16. Alver, A.; Basturk, E. Removal, of aspartame by catalytic ozonation with nano- $\mathrm{TiO}_{2}$ coated pumice. Desalin. Water Treat. 2019, $152,268-275$.

17. Saeid, S.; Kråkström, M.; Tolvanen, P.; Kumar, N.; Eränen, K.; Peurla, M.; Mikkola, J.-P.; Maël, L.; Kronberg, L.; Eklund, P.; et al. Synthesis, and characterization of metal modified catalysts for decomposition of ibuprofen from aqueous solutions. Catalysts 2020, 10, 786. [CrossRef]

18. Rathod, B.S.; Kumar, N. Ozone-A review. Int. J. Clin. Biomed. Res. 2015, 1, 102-108.

19. Okpala, R.C.O.; Bono, G.; Abdulkadir, A.; Madumelu, C.U. Ozone, $\left(\mathrm{O}_{3}\right)$ process technology (OPT): An exploratory brief of minimal ozone discharge applied to shrimp product. Energy Procedia 2015, 75, 2427-2435. [CrossRef]

20. Ghuge, P.S.; Saroha, A.K. Catalytic, ozonation for the treatment of synthetic and industrial effluents-Application of mesoporous materials: A review. J. Environ. Manag. 2018, 211, 83-102. [CrossRef]

21. Etchepare, R.; Oliveira, H.; Nicknig, M.; Azevedo, A.; Rubio, J. Nanobubbles: Generation using a multiphase pump, properties and features in flotation. Miner. Eng. 2017, 112, 19-26. [CrossRef]

22. Oliveira, H.; Azevedo, A.; Rubio, J. Nanobubbles, generation in a high-rate hydrodynamic cavitation tube. Miner. Eng. 2018, 116, 32-34. [CrossRef]

23. He, D.; Sun, Y.; Xin, L.; Feng, J. Aqueous, tetracycline degradation by non-thermal plasma combined with nano-TiO 2 . Chem. Eng. J. 2014, 285, 18-25. [CrossRef]

24. Wang, C.K.; Lin, C.-Y.; Liao, G.-Y. Degradation, of antibiotic tetracycline by ultrafine-bubble ozonation process. J. Water Process Eng. 2020, 37, 101463. [CrossRef]

25. Wang, C.K.; Jian, J.J. Feasibility of tetracycline wastewater degradation by an enhanced sonolysis. J. Adv. Oxid. Technol. 2015, 18, 39-46. [CrossRef]

26. Wang, X.; Wang, Y.; Li, D. Degradation, of tetracycline in water by ultrasonic irradiation. Water Sci. Technol. 2013, 67, 715-721. [CrossRef]

27. Wang, C.K.; Huang, B.M. Degradation, of tetracycline by advanced oxidation processes: Sono-Fenton and ozonation processes. Desalin. Water Treat. 2017, 96, 161-168. [CrossRef]

28. Urbano, R.V.; Maniero, M.G.; Perez-Moya, M.; Guimaraes, J.R. Influence, of pH and ozone dose on sulfaquinoxaline ozonation. J. Environ. Manag. 2017, 195, 224-231. [CrossRef]

29. Cao, J.; Xiong, Z.; Lai, B. Effect, of initial pH on the tetracycline (TC) removal by zero-valent iron: Adsorption, oxidation and reduction. Chem. Eng. J. 2018, 341, 492-499. [CrossRef]

30. Wang, C.K.; Lin, C.K. Study on the degradation of tetramethylammonium hydroxide using ultrasonic and ozone procedures. Desalin. Water Treat. 2019, 145, 309-317. [CrossRef] 
31. Wang, C.K.; Shih, Y.H. Degradation, and detoxicity of diazinon by sono-Fenton and sono-Fenton-like processes. Sep. Purif. Technol. 2015, 140, 6-12. [CrossRef]

32. Matsuura, K.; Nishiyama, T.; Sato, E.; Yamamoto, M.; Kamimura, T.; Takahashi, M.; Koike, K.; Horibe, H. Effect of temperature on degradation of polymers for photoresist using ozone microbubbles. J. Photopolym. Sci. Technol. 2016, 29, 623-627. [CrossRef]

33. Chuajedton, A.; Aoyagi, H.; Uthaibutra, J.; Pengphol, S.; Whangchai, K. Inactivation, of Escherichia coli O157:H7 by treatment with different temperatures of micro-bubbles ozone containing water. Int. Food Res. J. 2017, 24, 1006-1010.

34. Wu, J.; Gao, H.; Yao, S.; Chen, L.; Gao, Y.; Zhang, H. Degradation, of crystal violet by catalytic ozonation using Fe/activated carbon catalyst. Sep. Purif. Technol. 2015, 147, 179-185. [CrossRef]

35. Ai, C.; Zhou, D.; Wang, Q.; Shao, X.; Lei, Y. Optimization, of operating parameters for photocatalytic degradation of tetracycline using $\mathrm{In}_{2} \mathrm{~S}_{3}$ under natural solar radiation. Sol. Energy 2015, 113, 34-42. [CrossRef]

36. Mohsin, K.M.; Mohammed, A.A. Catalytic, ozonation for removal of antibiotic oxy-tetracycline using zinc oxide nanoparticles. Appl. Water Sci. 2021, 11. [CrossRef]

37. Yao, H.; Pei, J.; Wang, H.; Fu, J. Effect of Fe(II/III) on tetracycline degradation under UV/VUV irradiation. Chem. Eng. J. 2017, 308, 193-201. [CrossRef]

38. Halling-Sørensen, B.; Sengeløv, G.; Tjørnelund, J. Toxicity, of tetracyclines and tetracycline degradation products to environmentally relevant bacteria, including selected tetracycline-resistant bacteria. Arch. Environ. Contam. Toxicol. 2002, 42, $263-271$. [CrossRef] [PubMed] 